KRZYSZTOF ŚWIDERSKI*

\title{
Biurokratyczne załatwianie spraw
}

\section{Wprowadzenie}

Biurokracja stanowi przedmiot zainteresowania socjologii, nauk o organizacji i zarządzaniu, nauk politycznych oraz nauki administracji. Zjawisko biurokracji jest badane metodami i narzędziami badawczymi właściwymi dla różnych dyscyplin. Fragmentaryzacja i specjalizacja nauk społecznych oznacza wielodyscyplinarne badanie biurokracji, nie wyklucza jednak rozważań o charakterze konsiliencyjnym. Dlatego dokonując analizy przepisów prawnych, wolno uwzględnić także zjawiska, które mają znaczenie dla oceny tego, na czym polega biurokratyczne postępowanie podmiotów wykonujących administrację publiczną.

Celem artykułu jest próba ustalenia, w jakim znaczeniu ustawodawca posłużył się terminem "biurokratyczne załatwianie spraw" w art. 227 Ustawy z dnia 14 czerwca 1960 r. Kodeks postępowania administracyjnego ${ }^{1}$. Zadanie to - oprócz analizy przepisów o postępowaniu skargowym - wymaga sprawdzenia, czy i w jakim zakresie procedura administracyjna chroni obywatela przed negatywnymi skutkami działań biurokratycznych. Podstawę rozważań stanowią przepisy formułujące zasady postępowania administracyjnego i określające główne obowiązki funkcjonariuszy administracji publicznej. Należy odwołać się też do podstawowych zasad postępowania administracyjnego w instytucjach, organach, urzędach i agencjach Unii Europejskiej. Obok wyników analizy przepisów prawnych uwzględnienia wymaga to, $\mathrm{w}$ jaki sposób

\footnotetext{
* Krzysztof Świderski, dr, Samorządowe Kolegium Odwoławcze w Poznaniu, e-mail: kswiderski@gazeta.pl,https://orcid.org/0000-0003-1722-592X.

${ }^{1}$ Tekst jedn. Dz.U. 2020, poz. 256 ze zm., dalej „k.p.a.”.
} 
rozwój technologii informatycznych i technik biurowych oddziałuje na ograniczenie lub wzrost biurokratycznych mankamentów w obsłudze obywateli przez administrację publiczną. Prowadzi to do refleksji na temat zakresu zjawiska biurokratyzmu w epoce cyfryzacji i informatyzacji usług publicznych. Dalszym celem rozważań będzie wskazanie praktycznych konsekwencji dla obywateli, jakie można wyprowadzić z zakazu "biurokratycznego załatwiania spraw”.

Ponieważ art. 227 k.p.a. należy do kategorii przepisów o postępowaniu przed organami wykonującymi zadania z zakresu administracji publicznej, problem biurokratyzmu należy rozpatrywać właśnie na poziomie przepisów procesowych, a nie na poziomie struktur organizacyjnych. Kwestie odnoszące się do modelu ustrojowego i więzi organizacyjnych będą przywoływane tylko w koniecznym zakresie, gdy będzie mowa o samej biurokracji jako formie organizacji zarządzania. Zasadniczy tok rozważań odnosi się do procedury i uwarunkowań jej stosowania.

\section{Biurokratyczne załatwianie spraw jako przedmiot skargi powszechnej}

W świetle art. 227 k.p.a. biurokratyczne załatwianie spraw przez organy albo przez ich pracowników może być przedmiotem skargi powszechnej (actionis popularis). Przepis ten odnosi się do jurysdykcyjnego postępowania administracyjnego oraz innych postępowań administracyjnych stosowanych przy wykonywaniu zadań z zakresu administracji publicznej. Skargę można składać w interesie publicznym, własnym lub innej osoby za jej zgodą (art. $221 \S 3$ k.p.a.).

Instytucja skargi powszechnej skonstruowana na wzór sowiecki została wprowadzona do polskiego systemu prawnego na mocy wspólnej Uchwały Rady Państwa i Rady Ministrów z dnia 14 grudnia 1950 r. w sprawie rozpatrywania i załatwiania odwołań, listów i zażaleń ludności oraz krytyki prasowej ${ }^{2}$. We wstępie do uchwały wśród celów nowej regulacji wymieniono "skuteczne zwalczanie wypaczeń biurokratycznych". Natomiast w pkt 4 uchwały postanowiono, że osoby "przejawiające bezduszno-biurokratyczny, formalny stosunek do odwołań, listów i zażaleń obywateli powinny być pociągane do surowej

\footnotetext{
${ }^{2}$ M.P. 1951 Nr A-1, poz. 1.
} 
odpowiedzialności służbowej". Uchwała powyższa utraciła moc wraz z wejściem w życie w dniu 1 stycznia 1961 r. działu IV (art. 151-179) Kodeksu postępowania administracyjnego z dnia 14 czerwca 1960 r. zatytułowanego "Skargi i wnioski”

Skarga na biurokratyczne załatwianie spraw została przewidziana $\mathrm{w}$ art. 157 pierwotnego tekstu k.p.a. Przepis ten po zmianie numeracji został oznaczony jako art. 227 k.p.a. i obowiązuje do dziś w niezmienionym kształcie, poddany jedynie drobnej korekcie redakcyjnej.

Negatywny stosunek do biurokracji wyrażający się w zakazie "biurokratycznego załatwiania spraw" miał swoje odniesienia zarówno w propagandzie PRL, jak i w ówczesnym kontekście kulturowym nieprzychylnym dla urzędników ${ }^{4}$. W ustroju komunistycznym klasą przodującą byli robotnicy oraz robotnicy rolni, natomiast urzędnicy - zanim uzyskali oficjalny status inteligencji pracującej - mogli być postrzegani jako grupa społeczna nienadążająca za kierunkiem zmian społecznych. $\mathrm{W}$ tej sytuacji formalizm urzędniczy mógł być utożsamiany z negatywnie postrzeganym biurokratyzmem.

Zakres skargi powszechnej jest bardzo szeroki, przysługuje ona bowiem wszystkim obywatelom w stosunku nie tylko do organów administracji publicznej, ale również do organizacji i instytucji społecznych realizujących zadania w sektorze publicznym. Przedmiotem skargi może być działalność organów państwowych, organów przedsiębiorstw państwowych i innych państwowych jednostek organizacyjnych, organów jednostek samorządu terytorialnego, a także organów samorządowych jednostek organizacyjnych oraz organizacji i instytucji społecznych w związku z wykonywanymi przez nie zadaniami zleconymi z zakresu administracji publicznej (art. 2, art. $221 \S 1$ i 2, art. 224 k.p.a.). Do kategorii organizacji społecznych należą w szczególności organizacje zawodowe, samorządowe i spółdzielcze (art. 5 § 2 pkt 5 k.p.a.). Przepisy o skardze powszechnej odnoszą się też do działalności administracji skarbowej (art. $3 \S 1$ pkt 2 k.p.a.), polskich przedstawicielstw dyplomatycznych i urzędów konsularnych, a także do sfery wewnętrznej administracji

${ }^{3}$ Fakt utraty mocy przez omawianą uchwałę został potwierdzony dopiero Uchwałą Nr 304 Rady Ministrów z dnia 4 XII 1972 r. w sprawie utraty mocy obowiązującej niektórych uchwał Rady Ministrów, Prezydium Rządu, Komitetu Ekonomicznego Rady Ministrów i Komitetu Ministrów do Spraw Kultury, ogłoszonych w Monitorze Polskim (M.P. 1972 Nr 58, poz. 311).

${ }^{4}$ E. Żyrek-Horodyska, Biurokracja PRL-u w dokumencie Krzysztofa Kieślowskiego w kontekście powieści "Urząd" Tadeusza Brezy i publikacji z "Trybuny Ludu”, "Konteksty Kultury” 2015, t. 12, z. 3, s. 382-400. 
w zakresie podległości służbowej pracowników organów państwowych i państwowych jednostek organizacyjnych (art. 3 \& 4 k.p.a.). Skarga jest zatem szerokim środkiem kontroli sektora publicznego.

W kontekście powszechności skargi, o której mowa w art. 227 k.p.a., większego znaczenia nabiera również zakaz „biurokratycznego załatwiania spraw", adresowany do wszystkich podmiotów wykonujących zadania z zakresu administracji publicznej. Korelatem tego zakazu jest obowiązek bezstronnego i sprawnego załatwiania spraw administracyjnych. Zgodnie z art. 227 k.p.a. przedmiotem skargi może być w szczególności zaniedbanie lub nienależyte wykonywanie zadań przez właściwe organy albo przez ich pracowników, naruszenie praworządności lub słusznych interesów obywateli, a także przewlekłe lub biurokratyczne załatwianie spraw.

Należy postawić tezę, że w art. 227 k.p.a. pejoratywna ocena ustawodawcy nie odnosi się do samej biurokracji, lecz do biurokratyzmu jako dysfunkcji biurokracji. W latach siedemdziesiątych XX w. zwracano uwagę, że biurokracja jako model zarządzania sprawami publicznymi ma też negatywne metody działania, do których szczególną skłonność wykazuje "zawodowe urzędnictwo"

Ustawodawca, formułując zakaz załatwiania spraw w sposób biurokratyczny, nie odnosił się do biurokracji jako specyficznej struktury organizacyjnej, lecz do pewnego nagannego sposobu procedowania w konkretnej sprawie lub w jakiejś kategorii spraw administracyjnych. Samo pojęcie biurokracji powinno być traktowane neutralnie. Jest to pewien model organizacji pracy biurowej i administracyjnej w sektorze publicznym, ale obecny także w organizacjach komercyjnych.

\section{Biurokracja i jej dysfunkcje}

Termin "biurokracja” został wprowadzony do obiegu intelektualnego w połowie XVIII w. ${ }^{6}$ Twórcą najbardziej znanej koncepcji naukowej dotyczącej biurokracji był niemiecki socjolog, filozof i prawnik Max Weber (1864-1920). Idealny model biurokracji M. Webera opierał się na przekonaniu, że biurokratyczna administracja jest najbardziej racjonalną formą zarządzania państwem. Autor uważał, że cechami biurokracji są bezosobowe kontakty między urzędnikami, profesjonalizm, formalny

${ }^{5}$ M. Jaroszyński, Zagadnienia samorządu, „Państwo i Prawo” 1974, z. 6, s. 11.

${ }^{6}$ Jako autora terminu "biurokracja” wskazuje się fizjokratę Vincenta de Gournay (1712-1759). 
legalizm, hierarchiczność, ścisły podział kompetencji, obieg informacji $\mathrm{w}$ formie dokumentów ${ }^{7}$. W istocie jest to pruski (protestancki) model biurokracji, choć autor czerpał przykłady również z administracji brytyjskiej.

M. Weber charakteryzował idealny typ biurokracji następująco: „Zasadą są trwałe, ogólnie uporządkowane wedle reguł (praw lub regulaminów administracyjnych), kompetencje poszczególnych organów, a to oznacza, że 1) istnieje trwały podział niezbędnych dla celów tworu cechującego się panowaniem biurokratycznym, regularnych czynności jako urzędowych obowiązków. 2) Niezbędne do wypełnienia tych obowiązków uprawnienia rozkazodawcze są także trwale podzielone, zaś przypisane do nich ewentualne środki przymusu [...] są ściśle ograniczone regułami. 3) O regularne i ciągłe wypełnianie tak podzielonych obowiązków i urzeczywistnienie odpowiednich praw dba się planowo, zatrudniając osoby cechujące się ogólnie określonymi kwalifikacjami" ${ }^{\prime \prime}$.

Zarysowany wyżej idealny model biurokracji stanowi punkt odniesienia również dla współczesnych koncepcji zarządzania publicznego, tj. New Public Management, New Public Governance i New-Weberian State. Ramy instytucjonalne wyznaczone przez tzw. postbiurokrację z jednej strony nadal realizują postulaty instrumentalnej racjonalności, bezstronności i efektywności, a z drugiej - uwzględniają innowacyjność i połączenia sieciowe w miejsce hierarchicznych.

Mimo krytyki niektórych skutków biurokracji jako formy organizacji i zarządzania jednocześnie wskazuje się w polskiej literaturze na zalety biurokracji, takie jak: efektywność, obiektywizm, myślenie normatywne i standaryzacja ${ }^{9}$. „Pomimo swojej uciążliwości, biurokracja stanowi narzędzie organizacyjne, którego nie można zastąpić w administracji publicznej jakąkolwiek inną metodą zarządzania"10. W piśmiennictwie formułowana jest także teza, że biurokracja może być skutecznym i efektywnym sposobem organizacji pracy opartej na wiedzy ${ }^{11}$. Walory biurokracji dostrzegane są nie tylko w zarządzaniu sprawami publicznymi - w biurokracji upatruje się też ram organizacyjnych niezbędnych

${ }^{7}$ M. Weber, Gospodarka i społeczeństwo. Zarys socjologii rozumiejacej, tłum. D. Lachowska, Warszawa 2002, s. 161-168.

${ }^{8}$ Ibidem, s. 693.

${ }^{9}$ M. Kulesza, D. Sześciło, Polityka administracyjna i zarządzanie publiczne, Warszawa 2013, s. 52.

${ }^{10} \mathrm{M}$. Brol, Racjonalizacja działalności organizacji zbiurokratyzowanych, "Optimum. Studia Ekonomiczne" 2013 nr 1(61), s. 56.

${ }^{11}$ D. Jemielniak, W obronie biurokracji, "Master of Business Administration" 2010, nr 2, s. 72-79. 
do właściwego korzystania z wolności gospodarczej, jaką daje kapitalizm, jednocześnie chroniących społeczeństwo przed destrukcyjnymi działaniami poszukujących zysku jednostek ${ }^{12}$.

Na tle powyższych uwag nie dziwi postulat, aby w treści art. 227 k.p.a. zakaz biurokratycznego załatwiania spraw został zastąpiony nakazem biurokratycznego załatwiania spraw. „Uznanie, że «biurokratyczne załatwianie spraw» może być przedmiotem skargi, opiera się na zupełnym niezrozumieniu tego, na czym polega biurokracja i biurokratyczne załatwianie spraw", tj. "załatwianie ich zgodnie z zasadami biurokracji, czyli organizacji biurokratycznej [...], która to organizacja jest niczym innym jak materializacją koncepcji państwa prawnego"13.

Biurokracja jako mechanizm oparty na relacjach bezosobowych, procedurze i kompetencjach może niewątpliwie ułatwiać racjonalne i legalne wykonywanie zadań w sferze publicznej.

Niemniej przedmiotem skargi powszechnej i krytyki ustawodawcy nie jest biurokracja ujmowana jako model zarządzania administracją publiczna, lecz pewne dysfunkcje organizacji pracy biurowej w organach wykonujących zadania z zakresu administracji publicznej określone mianem biurokratyzmu.

Jednym z najbardziej znanych krytyków biurokratyzmu jako systemu organizacyjnego i jego skutków był Robert K. Merton (1910-2003). Dysfunkcje biurokracji według tego socjologa związane są z tym, że mechanizm biurokratyczny kształtuje szczególne cechy urzędnicze, takie jak: wyuczona bezradność, skrzywienie zawodowe, rutyna, uprzedzenia i antypatie wobec klientów, asekuranctwo, konformizm, nadmierny formalizm. W rezultacie pojawia się opór przed rozwiązywaniem sytuacji nietypowych, przed zmianami organizacyjnymi i wszelkimi innowacjami. Organizacja biurokratyczna skupia się na własnym funkcjonowaniu i zaczyna poszukiwać partykularnych celów, zamiast świadczyć usługi publiczne ${ }^{14}$.

Krytyczne oceny wobec skutków biurokratyzacji struktur organizacyjnych formułował również Michel Crozier (1922-2013). Według

${ }^{12}$ L. Drenda, Biurokracja a wolność społeczeństwa w systemie rynkowym, „Studia Ekonomiczne" 2013, t. 130, s. 11-18.

${ }^{13} \mathrm{~J}$. Supernat, Biurokratyczne załatwianie spraw jako przedmiot skargi powszechnej - uwagi de lege lata $i$ de lege ferenda, w: Kodyfikacja postępowania administracyjnego na 50-lecie K.P.A., pod red. J. Niczyporuka, Lublin 2010, s. 772.

${ }^{14}$ R.K. Merton, Teoria socjologiczna i struktura społeczna, tłum. E. Morawska, J. Wertenstein-Żuławski, Warszawa 2002, s. 258-261. 
niego zagrożeniem jest nie tylko autonomizacja personelu instytucji biurokratycznej, ale również autonomizacja celów tej instytucji. Patologia biurokratyzmu przejawia się m.in. w niewłaściwym przystosowaniu instytucji do otoczenia społecznego, nieadekwatności zastosowanych rozwiązań do wcześniej wyznaczonych celów, a także w nadmiernym formalizmie i rutynie. Trwałość zrutynizowanych i zautonomizowanych procedur biurokratycznych wynika $z$ hamowania wszelkiej inicjatywny indywidualnej, centralizacji podejmowania decyzji, izolacji poszczególnych warstw personelu oraz izolacji grup kierowniczych, czemu towarzyszy silny, dyscyplinujący nacisk na poszczególnych pracowników i ich grupy. W rezultacie wśród urzędników rodzi się frustracja w klimacie bezosobowości i centralizacji, co przekłada się na napięcia i wrogość w kontaktach pomiędzy urzędnikami a interesantami ${ }^{15}$.

Chociaż wielu autorów sądzi, że dysfunkcje są wpisane w istotę mechanizmu biurokratycznego, to jednak ograniczając pole widzenia do samego przepisu art. 227 k.p.a., można założyć, że biurokracja sama w sobie jest neutralna. Na potrzeby rozważań prowadzonych wokół instytucji skargi powszechnej, przewidzianej w art. 227 k.p.a., przyjąć należy, że "biurokratyczne załatwianie spraw" oznacza pewien sposób wykonywania pracy biurowej. Nie musimy zatem nawiązywać do biurokracji jako systemu reguł instytucjonalnych i ram działania czy organizacji zarządzania sektorem publicznym.

Pojęcie "biurokratycznego załatwiania spraw" jest raczej związane z kulturą organizacji niż z oceną samej organizacji. W tym kontekście biurokratyzm jako dysfunkcja biurokracji jest rezultatem zachowania urzędników. Podstawy tego zachowania wyznaczone są przez brak etosu pracy, niskie standardy zawodowe i etyczne oraz niską kulturę administrowania. Przejawem biurokratycznego działania urzędnika są jego zachowania nacechowane poczuciem wyższości wobec petenta, powodujące stan niepewności i napięcia w kontaktach z interesantem.

\section{Ogólne zasady postępowania i obowiązki urzędnika}

Przedmiotem skargi wymienionej w art. 227 k.p.a. mogą być nie tylko błędy w funkcjonowaniu organów administracji jako jednostek organizacyjnych, ale także naruszenia dokonywane przez konkretnego pracownika. s. 297.

${ }^{15}$ M. Crozier, Biurokracja. Anatomia zjawiska, tłum. S. Łypacewicz, Warszawa 1967, 
W takim przypadku skargę może rozpoznać przełożony służbowy pracownika (art. $232 \S 2$ k.p.a.). Zgodnie z art. 14a k.p.a. organ administracji publicznej powinien umożliwić stronom ocenę pracowników urzędu kierowanego przez ten organ. Ustawodawca nie określił, w jakim trybie i zakresie organ administracji publicznej powinien umożliwić stronom ocenę działania konkretnego pracownika urzędu. Należy jednak przyjąć, że art. 14a k.p.a. przyznaje uprawnienie do oceny pracowników urzędu tylko stronie postępowania i tylko w zakresie zachowania urzędnika w tym konkretnym postępowaniu, w którym strona uczestniczy. Powołany przepis stanowi w pewnym stopniu uzupełnienie przepisów o postępowaniu w sprawie skarg, wniosków oraz petycji ${ }^{16}$. Niemniej w przypadku wniesienia skargi, wniosku czy petycji podmiot wykonujący zadania z zakresu administracji publicznej ma obowiązek udzielenia odpowiedzi, natomiast organ, któremu strona przedstawiła ocenę działania pracownika urzędu, nie został zobowiązany do udzielenia odpowiedzi.

Zgodnie $z$ art. 14a k.p.a. uprawnienie do oceny działania urzędu oraz pracownika tego urzędu przysługuje tylko stronie, lecz skargę na biurokratyczne załatwianie spraw może wnieść każdy (art. 221 ust. 1 k.p.a.), jeżeli zatem skargę taką wnosi osoba niemająca statusu strony postępowania, to organ prowadzący postępowanie powinien ją rozpatrzyć z urzędu (zob. art. 233 i 234 k.p.a.), jak każdy inny materiał złożony do akt sprawy.

Przewidziana w art. 227 k.p.a. skarga na biurokratyczne załatwianie spraw nie odnosi się do biurokracji jako struktury organizacyjnej, nie stanowi krytyki ustroju władz publicznych. Jak wcześniej wskazano, przepis art. 227 k.p.a. wywodzi się z czasów, gdy państwo socjalistyczne i jego ustrój były uważane za najwyższy etap rozwoju społecznego. Przedmiotem krytyki nie mógł być więc ustrój aparatu władzy, lecz pewne biurokratyczne mankamenty, za które odpowiadali "bezduszni urzędnicy”.

Podążając za tym kierunkiem interpretacji art. 227 k.p.a., należy powiązać krytykę „biurokratycznego załatwiania spraw” z krytyką niektórych zachowań funkcjonariuszy publicznych. Chodzi o takie zachowania, które nie znajdują akceptacji ani w świetle prawa, ani w świetle norm obyczajowych i etycznych.

Zgodnie z art. 17 ust. 1, ust. 2 pkt 2, 4, 7 Ustawy z dnia 16 września 1982 r. o pracownikach urzędów państwowych ${ }^{17}$ urzędnik państwowy

${ }^{16}$ K. Glibowski, Komentarz do art. 14a, w: Kodeks postepowania administracyjnego. Komentarz, pod red. R. Hausera, M. Wierzbowskiego, Warszawa 2018, s. 155.

${ }^{17}$ Tekst jedn. Dz.U. 2020, poz. 537 ze zm. 
jest obowiązany chronić prawa i słuszne interesy obywateli; dążyć do pogłębiania zaufania obywateli do organów państwa; rzetelnie i bezstronnie, sprawnie i terminowo wykonywać powierzone zadania; godnie zachowywać się $\mathrm{w}$ pracy oraz poza nią. Z kolei zgodnie $\mathrm{z}$ art. 24 ust. 2 pkt 2, 3, 5, 6 Ustawy z dnia 21 listopada 2008 r. o pracownikach samorządowych $^{18}$ do obowiązków pracownika samorządowego należy w szczególności wykonywanie zadań sumiennie, sprawnie i bezstronnie; udzielanie informacji osobom fizycznym oraz udostępnianie dokumentów; zachowanie uprzejmości i życzliwości w kontaktach $\mathrm{z}$ obywatelami; zachowanie się z godnością $\mathrm{w}$ miejscu pracy i poza nim. Podobne wymagania dotyczą członków korpusu służby cywilnej, którzy w myśl art. 76 ust. 1 pkt 2, 4, 7 Ustawy z dnia 21 listopada 2008 r. o służbie cywilnej ${ }^{19}$ mają obowiązek chronić prawa człowieka i obywatela; rzetelnie i bezstronnie, sprawnie i terminowo wykonywać powierzone zadania; godnie zachowywać się w służbie oraz poza nią.

Naruszenie sformułowanych wyżej standardów może spowodować konsekwencje w postaci pociągnięcia pracownika do odpowiedzialności porządkowej lub dyscyplinarnej. Powtarzające się negatywne opinie okresowe wystawione pracownikowi administracji przez jego przełożonych w ramach ocen kwalifikacyjnych mogą spowodować usunięcie ze służby.

Niezależnie od osobistej odpowiedzialności urzędnika tamę dla złych praktyk urzędniczych stanowią zasady ogólne postępowania administracyjnego. Przyjaznego podejścia urzędnika do sytuacji petenta wymaga zasada budowania zaufania obywateli do władzy publicznej, połączona z regułami proporcjonalności, bezstronności i równego traktowania (art. 8 \& 1 k.p.a.). Urzędnik jest zobowiązany do należytego i wyczerpującego informowania uczestników postępowania o mających znaczenie okolicznościach faktycznych i prawnych, a nadto do udzielania im niezbędnych wyjaśnień i wskazówek, tak aby nie ponieśli szkody z powodu nieznajomości prawa (art. 9 k.p.a.). Urzędnik wyznaczony do prowadzenia postępowania powinien działać w sprawie wnikliwie i szybko (art. $12 \S 1$ k.p.a.), a także dążyć do polubownego rozstrzygnięcia kwestii spornych oraz ustalenia praw i obowiązków będących przedmiotem postępowania (art. 13 k.p.a.). Organ administracji publicznej obowiązany jest zapewnić stronom czynny udział w każdym stadium postępowania (art. $10 \S 1$ k.p.a.) oraz wyjaśnić stronom

\footnotetext{
${ }^{18}$ Tekst jedn. Dz.U. 2019, poz. 1282 ze zm.

${ }^{19}$ Tekst jedn. Dz.U. 2020, poz. 265 ze zm.
} 
zasadność przesłanek, którymi organ kierował się przy załatwieniu sprawy (art. 11 k.p.a.).

Samo istnienie powyższych reguł procesowych tworzy system zabezpieczający obywatela przed przejawami biurokratyzmu. Dla praktyki znaczenie mają jednak realia funkcjonowania danej jednostki organizacyjnej (urzędu). Brak etatów, niewystarczające środki budżetowe, brak szkoleń, przestarzałe urządzenia biurowe czy wypalenie zawodowe pracowników będą determinowały jakość obsługi petenta, niezależnie od przysługujących mu formalnych gwarancji procesowych.

Polska jako kraj członkowski Unii Europejskiej (UE) zainteresowana jest również zapewnieniem właściwego działania urzędników zatrudnionych w instytucjach, organach, urzędach i agencjach UE. W myśl art. 41 Karty Praw Podstawowych UE (KPP), która została proklamowana w dniu 7 grudnia 2000 r. na szczycie UE w Nicei, każdy ma prawo do bezstronnego i sprawiedliwego rozpatrzenia swojej sprawy w rozsądnym terminie przez instytucje, organy i jednostki organizacyjne Unii (ust. 1). Prawo to obejmuje: a) prawo każdego do bycia wysłuchanym, zanim zostaną podjęte indywidualne środki mogące negatywnie wpłynąć na jego sytuację; b) prawo każdego do dostępu do akt jego sprawy, przy poszanowaniu uprawnionych interesów poufności oraz tajemnicy zawodowej i handlowej; c) obowiązek administracji uzasadniania swoich decyzji (ust. 2). Gwarancje procesowe wymienione w art. 41 KPP określane są mianem prawa do dobrej administracji (the right to good administration).

Reguły ujęte w art. $41 \mathrm{KPP}$ zostały uszczegółowione w uchwalonym przez Parlament Europejski w dniu 6 września 2001 r. Europejskim Kodeksie Dobrej Praktyki Administracyjnej (The European Code of Good Administrative Behaviour), który w polskim tłumaczeniu znany jest jako Europejski Kodeks Dobrej Administracji (EKDA) ${ }^{20}$. Akt ten ma cechy instrukcji i zaleceń skierowanych do urzędników unijnych, pokazując sposób właściwego działania; nie ma powszechnej mocy obowiązującej $^{21}$. Kodeks określa zasady dobrej praktyki administracyjnej znajdujące zastosowanie w odniesieniu do całości kontaktów instytucji unijnych i ich urzędników z jednostką (art. 3 ust. 1). Urzędnik powinien działać bezstronnie, uczciwie i rozsądnie (art. 11), przestrzegać prawa (art. 4)

${ }^{20}$ J. Świątkiewicz, Europejski Kodeks Dobrej Administracji (tekst i komentarz o zastosowaniu kodeksu w warunkach polskich procedur administracyjnych), Warszawa 2002.

${ }^{21}$ L. Leszczyński, Europejski Kodeks Dobrej Administracji a zasady polskiej procedury administracyjnej, w: Europeizacja prawa administracyjnego, pod red. I. Rzucidło, Lublin 2011, s. 13. 
oraz nie nadużywać uprawnień (art. 7). W swoich kontaktach z jednostką urzędnik pozostaje usługodawcą i zachowuje się właściwie, uprzejmie i pozostaje dostępny (art. 12 ust. 1).

Obok art. 41 KPP, który otrzymał rangę traktatową w 2007 r. na mocy traktatu reformującego UE (tzw. traktat lizboński), drugą podstawę do wyznaczenia zakresu obowiązków urzędników unijnych stanowi art. 298 ust. 1 Traktatu o funkcjonowaniu Unii Europejskiej (TFUE). W myśl tego przepisu instytucje, organy i jednostki organizacyjne Unii, wykonując swoje zadania, korzystają ze wsparcia otwartej, efektywnej i niezależnej administracji europejskiej (open, efficient and independent European administration). Z kolei na podstawie art. 298 ust. 2 TFUE Parlament Europejski i Rada otrzymały umocowanie do konsolidacji i ujednolicenia przepisów o postępowaniu administracyjnym $\mathrm{w}$ drodze rozporządzenia zgodnie ze zwykłą procedurą ustawodawczą. Pomimo kolejnych rezolucji Parlamentu Europejskiego zlecających Komisji Europejskiej przygotowanie aktu regulującego postępowanie administracyjne przed organami i instytucjami unijnymi zadanie nie zostało wykonane ${ }^{22}$.

Z tego skrótowego zestawienia wynika, że kontakt polskiego obywatela $\mathrm{z}$ administracją unijną powinien być wolny od mankamentów biurokratyzmu. Funkcjonowanie otwartej, efektywnej i niezależnej administracji europejskiej oraz uznanie prawa jednostki do dobrej administracji powinny - przynajmniej w założeniu - tworzyć gwarancje procesowe zabezpieczające słuszne interesy jednostki. Europejskie standardy dobrej administracji i tzw. dobre praktyki administracyjne, wywiedzione także z orzecznictwa Trybunału Sprawiedliwości UE, w niczym nie wyprzedzają tego, co gwarantuje polskie prawo krajowe. Regulacje europejskie, tak samo jak ustawodawstwo polskie, zmierzają do takiego ukształtowania procedury administracyjnej, aby nie tworzyć miejsca dla zachowań biurokratycznych.

\section{Znaczenie dokumentu i technologii informatycznych w ograniczaniu biurokratyzmu}

Biurokratyzm w potocznym znaczeniu utożsamiany jest nie tylko z arogancją i niechęcią wobec obywatela, ale przede wszystkim kojarzony z przesadnym formalizmem i mnożeniem dokumentów wymaganych

${ }^{22}$ Rezolucja PE z dnia 15 I 2013 r. nr 2012/2024(INL); rezolucja PE z dnia 9 VI 2016 r. nr 2016/2610(RSP); pkt 34 rezolucji PE z dnia 26 X 2017 r. nr 2017/2011(INI). 
do załatwienia określonej sprawy administracyjnej. Urzędnik, który na pierwszym miejscu stawia asekuranctwo i konformizm albo zamierza zniechęcić petenta, będzie wzywał do przedłożenia kolejnych zaświadczeń, oświadczeń, wypisów z rejestrów publicznych, odpisów dokumentów urzędowych, uwierzytelnionych wyciągów z dokumentów, ekspertyz prywatnych, materiałów kartograficznych itd. Ustawodawca wprawdzie ograniczył formalizm, wprowadzając do jurysdykcyjnego postępowania administracyjnego zasadę niekomplikowania postępowania (art. $12 \S 1$ k.p.a.), uproszczone reguły uwierzytelniania kopii dokumentów (art. 76a k.p.a.), zakaz żądania zaświadczeń lub oświadczeń na potwierdzenie niektórych faktów lub stanu prawnego (art. $220 \S 1$ k.p.a.), a także zasadę rozstrzygania niedających się usunąć wątpliwości co do stanu faktycznego na korzyść strony (art. 81a § 1 k.p.a.), niemniej w praktyce urzędniczej powyższe reguły mogą być omijane poprzez zbyt szerokie stosowanie wyjątków od tychże reguł.

Należy przypomnieć, że posługiwanie się dokumentem jest czynnikiem warunkującym biurokrację. Biurokracja jako mechanizm legalnego wykonywania władzy posługuje się dokumentem w celu wydawania poleceń i wytycznych do struktur podległych, które z kolei przekazują do organów zwierzchnich raporty i zbiory informacji. Archiwa i inne uporządkowane zbiory dokumentów stanowią bazę wiedzy gromadzonej przez biurokrację. Dokument jest również podstawowym narzędziem oddziaływania na obywateli. Poprzez wydawanie pisemnych zezwoleń, dyspens od zakazów, zaświadczeń i innych przejawów władczego kształtowania sytuacji obywateli biurokracja zarządza sprawami publicznymi.

Tworzenie nadmiernej liczby dokumentów, jako przejaw biurokratyzmu, pozostaje w ścisłym związku z rozwojem technik biurowych i kancelaryjnych. Tok urzędowania zależy poniekąd od dostępnych technik rejestrowania informacji. Inny charakter ma system biurokratyczny oparty na dokumentach pisanych ręcznie, a zupełnie inne możliwości działania biurokratycznego daje druk i szybkie powielanie dokumentów. Coraz nowocześniejsze urządzenia biurowe, które służą do tworzenia dokumentów (np. maszyna do pisania, komputer, drukarka, kserokopiarka), dają urzędnikom możliwość intensyfikacji wymiany korespondencji z petentem i wzywania go do dostarczenia kolejnych dokumentów wymaganych do załatwienia sprawy. Taki rodzaj wzmożonego zarządzania poprzez dokumenty może być przez obywateli odbierany jako przejaw biurokratyzmu. 
Współczesny rozwój technologii informatycznych i upowszechnienie środków komunikacji elektronicznej zmieniły oblicze biurokracji. Pejoratywnie oceniany biurokratyzm, którego pojmowanie zostało zredukowane do zjawiska mnożenia zbędnych dokumentów papierowych, może niebawem stanowić zamknięty rozdział. Zarządzanie obiegiem dokumentów papierowych i tworzenie papierowych rejestrów pozostawiało miejsce na dyskrecjonalne działania urzędników. Nadmierny formalizm wsparty dokumentami mógł służyć zasłanianiu urzędniczej bezradności, konformizmu, braku wiedzy i rutyny.

Cyfryzacja administracji zmieniła bardzo wiele w relacjach urzędnik-obywatel. $W$ przypadku spraw załatwianych za pośrednictwem publicznych platform cyfrowych mamy do czynienia z pełną automatyzacją i zakodowanym algorytmem. $W$ rezultacie nie ma miejsca na ludzką manipulację. Zostaje poniekąd spełniony Weberowski postulat instrumentalnej racjonalności, bezstronności i efektywności. Elektroniczna biurokracja może przynieść kres niektórym dysfunkcjom biurokracji. O sposobie załatwienia konkretnej sprawy będzie decydował zautomatyzowany system, co spowoduje, że urzędnicze uprzedzenia i antypatie wobec klientów, asekuranctwo, brak kompetencji i konformizm nie dotkną petenta.

Ale elektroniczna administracja może stać się wyzwaniem także dla klienta. Precyzja elektronicznych procedur nie pozostawia miejsca na dowolność i arbitralność urzędnika, ale zarazem stawia takie same ograniczenia obywatelowi. Komputerowe formularze nie pozwalają na wprowadzanie jakichkolwiek danych nieodpowiadających sztywnym regułom. System odrzuci wszystko, co będzie niezgodne z zaprogramowanym algorytmem. W ten sposób petent nie będzie mógł powoływać się na jakieś szczególne okoliczności osobiste, które wcześniej mógł przedstawić na piśmie.

Współcześnie dostęp do e-administracji staje się coraz szerszy, nie tylko za sprawą publicznych platform (e-PUAP, Profil Zaufany, e-Dowod, e-Biznes). Obywatele, którzy korzystają z e-bankowości, tym samym otrzymują dostęp do wielu e-usług publicznych.

Biurokratyzm krytykowany w art. 227 k.p.a. jest utożsamiany z uciążliwymi dla obywatela przejawami specyficznej mentalności urzędniczej (np. konformizm, wyuczona bezradność, arogancja), a także z nadmiernym formalizmem związanym z zarządzaniem poprzez dokumenty. Elektroniczna administracja przerywa napięcie na linii urzędnik-obywatel. Zarazem jednak elektroniczny obieg dokumentów podlega pełnej 
formalizacji połączonej z absolutną precyzją $\mathrm{w}$ stopniu nieznanym nawet idei biurokracji M. Webera.

Przepis art. 227 k.p.a. stanowi wyraz negatywnej oceny dysfunkcji tradycyjnej biurokracji, której podstawowym narzędziem był dokument papierowy. Proces digitalizacji dokumentów papierowych i ich migracja do systemów informatycznych, a także tworzenie nowych dokumentów w formie cyfrowej, otwiera nowy rozdział w dziejach biurokracji. Publiczne zarządzanie poprzez e-dokument powoduje, że procedura załatwiania spraw administracyjnych jest w pełni obrazowana przez oprogramowanie kancelaryjne do zarządzania obiegiem danych.

Ustawodawca, krytykując biurokratyzm zdiagnozowany w połowie XX w., nie mógł przewidzieć, jaka będzie pozycja obywatela wobec e-biurokracji, której fundamentem stał się e-dokument. W tym kontekście określony w art. 227 k.p.a. zakaz „biurokratycznego załatwiania spraw" stracił na aktualności. Być może przyszłość pozwoli zdefiniować nowe zagrożenia dla obywateli wynikające z e-biurokracji. Wówczas pojęcie "biurokratycznego załatwiania spraw" może otrzymać nowy desygnat i zaktualizować podstawę skargi powszechnej.

Powyższe uwagi znajdują odniesienie do spraw administracyjnych, w których występuje tylko jedna strona postępowania. Tym samym mamy do czynienia z relacją dwupodmiotową: urząd-obywatel, którą można skutecznie zautomatyzować wedle określonego algorytmu. Taki zabieg nie będzie możliwy w przypadku spraw administracyjnych, w których występuje wiele stron o sprzecznych interesach. Wskazać należy zwłaszcza tzw. postępowania masowe, w których uczestniczy kilkadziesiąt lub nawet kilkaset stron. Prawidłowy przebieg takiej procedury wymaga pełnego informowania stron o przebiegu postępowania i elementach projektowanego rozstrzygnięcia, co pozwoli stronom ocenić ewentualne skutki dla ich praw i interesów ${ }^{23}$. Jako przykład postępowań z udziałem dużej liczby stron można wskazać postępowania zmierzające do wydania decyzji o lokalizacji inwestycji celu publicznego lub decyzji określającej środowiskowe uwarunkowania przedsięwzięcia mogącego znacząco oddziaływać na środowisko. Takie postępowania administracyjne z udziałem znacznej liczby stron o rozbieżnych interesach wymagają bardziej złożonych działań ze strony pracowników administracji. Korzystanie z systemów teleinformatycznych urzędu ograniczone jest zasadniczo do procedury publicznych ogłoszeń o treści

${ }^{23}$ A. Skóra, Wspótuczestnictwo w postępowaniu administracyjnym, Warszawa 2009, s. 122. 
złożonych wniosków, o terminach zgłaszania uwag, o wydanych postanowieniach lub decyzjach (art. 49-49b k.p.a.).

W postępowaniach administracyjnych, w których współuczestniczy wiele stron o sprzecznych interesach, do urzędnika należy kierowanie przebiegiem postępowania dowodowego oraz ocena zebranego materiału dowodowego. To funkcjonariusz wyznaczony do przeprowadzenia postępowania dokonuje oceny wiarygodności dowodów, uznaje określone okoliczności za uprawdopodobnione lub nie, weryfikuje poprawność formalną i merytoryczną podań. Urzędnik zachowuje więc duży zakres władzy dyskrecjonalnej, co daje pole do ujawnienia zachowań nagannych, będących pochodną rutyny, konformizmu, arogancji lub braku wiedzy. Działania takie mogą wypełniać znamiona "biurokratycznego załatwiania spraw".

Postrzeganie problematyki biurokratyzmu zachowuje aktualność również w przypadku tzw. administracji pierwszego kontaktu (ang. streetlevel bureaucracy, fr. politiques du guichet). Tutaj nadal relacje interpersonalne mają pierwszoplanowe znaczenie. Według tezy sformułowanej przez Michaela Lipsky'ego (ur. 1940) administracja pierwszego kontaktu to działania podejmowane przez wyspecjalizowanych pracowników służb publicznych, np. policjantów, strażaków, lekarzy, pielęgniarki, nauczycieli, pracowników socjalnych, pracowników służb komunalnych. To oni stanowią łącznik pomiędzy obywatelem a zorganizowaną i hierarchiczną władza, która kreuje polityki publiczne i ocenia ich efektywność. Funkcjonariusze zaliczeni do grupy pierwszego kontaktu pracują bezpośrednio z obywatelami lub, ogólniej, odbiorcami usług publicznych. Od tego, w jaki sposób korzystają z przyznanych im kompetencji, dostępu do zastrzeżonych informacji, uprawnienia do nakładania kar, zależy postrzeganie całej władzy publicznej przez obywateli24 ${ }^{24}$

W polskich warunkach za administrację pierwszego kontaktu należy uznać przede wszystkim pracowników gminnych ośrodków pomocy społecznej, a zwłaszcza pracowników socjalnych przeprowadzających rodzinny wywiad środowiskowy ${ }^{25}$. Do administracji pierwszego kontaktu należy zaliczyć także pracowników powiatowych urzędów pracy ${ }^{26}$.

${ }^{24}$ M. Lipsky, Street-Level Bureaucracy: The Dilemmas of the Individual in Public Services, New York 1980.

${ }^{25}$ Zob. M. Trochymiak, Uznaniowość w pomocy społecznej. Działania pracowników socjalnych w świetle koncepcji street-level bureaucracy, „Polityka Społeczna” 2018, nr 9, s. 12-18.

${ }^{26}$ Zob. K. Sztandar-Sztanderska, Czego nie widać? Literatura o polityce rynku pracy a praktyki urzędników pierwszego kontaktu, „Studia z Polityki Publicznej” 2017, nr 2(14), 
Wydaje się, że za urzędników pierwszego kontaktu można uznać nie tylko pracowników obsługujących petentów (tzw. front desk), ale również wykwalifikowanych kontrolerów wykonujących w terenie zadania powierzone inspekcji sanitarnej, inspekcji weterynaryjnej, inspekcji handlowej oraz pozostałym inspekcjom.

$\mathrm{W}$ codziennej pracy urzędnik pierwszego kontaktu rozwiązuje liczne dylematy powstające na styku stosowania ustawowych i politycznych zasad pomocy rodzinie czy promocji zatrudnienia a praktyką zdeterminowaną przez trudnych klientów, szczupłość środków do rozdysponowania oraz chęć uzyskania dobrych statystyk efektywności pracy. W rezultacie wielu urzędników wbrew osobistemu poczuciu sprawiedliwości poddaje się rutynie i konformizmowi, wchodząc tym samym w sferę biurokratyzmu.

Niemniej zakres władzy dyskrecjonalnej urzędników pierwszego kontaktu maleje, gdyż komputeryzacja i automatyzacja stopniowo wchodzą także na ten podstawowy, pierwszy poziom obsługi petenta. Klienci składają wnioski elektroniczne, a potrzebne informacje uzyskują $\mathrm{z}$ witryn internetowych. $\mathrm{Z}$ upływem czasu administracja pierwszego kontaktu, tzw. street-level bureaucracy, zmienia się w screen-level bureaucra$c y$, czyli administrację wykonywaną z poziomu ekranu komputerowego. Urzędników wyręczają eksperci IT, którzy w wyznaczonych ramach prawnych i wedle ustalonej siatki pojęć tworzą algorytmy do obsługi petentów oraz ścieżki decyzyjne ${ }^{27}$.

\section{Podsumowanie}

Wracając do głównego wątku rozważań, należy postawić pytanie o aktualność krytyki biurokratyzmu zamieszczonej w art. 227 k.p.a. Ustawodawca uznaje zjawisko "biurokratycznego załatwiania spraw” za naganne, godzące w słuszny interes obywateli, w ich prawo do dobrej administracji. Zjawisko to wynika z nawyków urzędniczych, uprzedzeń i antypatii wobec klientów, asekuranctwa, konformizmu i braku kompetencji pracowników administracji. Biurokratyzm manifestuje

\footnotetext{
s. 117-142; eadem, Obywatel spotyka państwo. O urzędach pracy jako biurokracji pierwszego kontaktu, Warszawa 2016, s. 17-34.

${ }^{27}$ M. Bovens, S. Zouridis, From Street-Level to System-Level Bureaucracies: How Information and Communication Technology is Transforming Administrative Discretion and Constitutional Control, „Public Administration Review” 2002, vol. 62, no. 2, s. 177.
} 
się w nadmiernym formalizmie i nakładaniu na obywatela obowiązku przedłożenia jak największej liczby dokumentów, co składa się na tzw. mitręgę urzędową.

Wymienione mankamenty $\mathrm{w}$ zamyśle ustawodawcy działającego $\mathrm{w}$ realiach istniejących $\mathrm{w}$ połowie $\mathrm{XX} \mathrm{w}$. miały ulec naprawie poprzez wyposażenie obywatela w prawo do wniesienia skargi na urzędnika przejawiającego "bezduszno-biurokratyczny” stosunek do petenta. Współcześnie jednak rozwiązanie legislacyjne zaproponowane w art. 227 k.p.a. traci coraz bardziej na aktualności. Podstawową przyczyną takiego stanu rzeczy jest szybkie wkraczanie technologii informatycznych do współczesnej administracji. Konstytutywnym narzędziem administracji staje się e-dokument i automatyzacja relacji obywatel-organ administracji. W przypadku relacji bezosobowych i sztywnych reguł komunikacji opartych na algorytmie czynnik ludzki traci znaczenie. Załatwianie przez obywatela spraw za pomoca systemu teleinformatycznego eliminuje wszystkie te okoliczności, które były charakterystyczne dla relacji interpersonalnych. Usunięte zatem zostaną problemy wynikające ze szczególnej mentalności urzędniczej i maniery biurokratycznego załatwiania spraw. Trzeba jednak pamiętać, że część funkcjonariuszy właściwie pojmuje i wykonuje swoje zadania. Zastąpienie ich przez systemy tworzone przez ekspertów IT oznacza dla obywateli, że nie będą mogli w trudnych przypadkach otrzymać bezpośredniej pomocy u fachowego i okazującego empatię urzędnika.

Z perspektywy zachodzących zmian technologicznych w administracji publicznej należy dostrzec, że stale zmniejsza się zbiór desygnatów pojęcia "biurokratyczne załatwianie spraw”. Coraz mniejsza liczba interakcji personalnych na linii obywatel-urzędnik powoduje, że urzędnicy tracą władzę dyskrecjonalną i tym samym sposobność do nagannych zachowań. Niemniej, jak się wydaje, jest za wcześnie, aby zakaz "biurokratycznego załatwiania spraw” uznać za relikt dawnych czasów i postulować wykreślenie tego sformułowania z treści art. 227 k.p.a. Nie mamy jeszcze pełnego obrazu, jak będzie wyglądała e-administracja i jakie są granice jej rozwoju. Nie można wykluczyć, że również administracja wspomagana przez technologie informatyczne będzie wykazywała określone dysfunkcje. Być może poziom formalizmu i tworzenia sztywnych rozwiązań spowoduje zagrożenie dla słusznych interesów obywateli nie mniejsze niż zagrożenie wynikające z uznaniowości pracowników administracji. Dlatego nie da się wykluczyć, że skarga na "biurokratyczne załatwianie spraw" stanie się w przyszłości 
ważnym środkiem obrony przed nowymi dysfunkcjami e-administracji. Będzie to już jednak inny biurokratyzm niż ten, któremu przeciwdziałał ustawodawca, kształtując treść art. 227 k.p.a.

Przekonanie o trwałości biurokracji jest obecne nie tylko w potocznym myśleniu, ale bywa akcentowane także w życiu publicznym. Jako znamienny przykład należy zacytować słowa Ronalda Reagana (19112004), byłego prezydenta Stanów Zjednoczonych, który stwierdził, że „biurokracja ze wszystkich rzeczy ziemskich jest najbliższa życiu wiecznemu: raz ustanowiona, nigdy się nie kończy"28.

\section{BUREAUCRATIC DISPOSAL OF MATTERS}

\section{Sum mary}

The article presents the issue of a bureaucratic disposal of matters by public administration authorities. The letter of dissatisfaction was introduced into Polish law as early as 1950. It was an expression of a negative attitude towards red tape. The prohibition of a bureaucratic disposal of matters is a guideline for the entire public sector. Bureaucracy is the negative behavior of officials: learned helplessness, routine, prejudices against applicants, assurance, conformism, and excessive formalism. The legislator's pejorative assessment does not refer to bureaucracy itself, but to red tape as a dysfunction of bureaucracy. Red tape is the result of organizational culture. The article presents the model of Weberian bureaucracy and a critique of it. The provisions obliging officials to act in an fair, impartial, reasonable and proper manner are discussed, and the example is given of proper, open, efficient and independent European Union administration. The tool that determines bureaucracy is the document. The creation of excessive amounts of documents, as a manifestation of bureaucracy (red tape), is closely related to the development of office techniques. However, the development of information technology and the dissemination of electronic communication channels have changed the face of bureaucracy. The direct contact between an official with an applicant is changing into screen-level bureaucracy, with the claimant's application being handled by the IT system. The official's discretionary power has Hus been significantly reduced. The development of e-administration eliminates inappropriate actions of officials. However, a new type of bureaucracy is emerging by IT experts. Art. 227 of the Code of Administrative Proceedings can become a protective measure against the formalism of e-government.

Keywords: letter of dissatisfaction - bureaucracy - red tape - administrative proceedings

${ }^{28}$ R. Reagan, Moja wizja Ameryki. Najważniejsze przemówienia 40. prezydenta Stanów Zjednoczonych, Warszawa 2004, s. 24. 


\section{LITERATURA}

Bovens M., Zouridis S., From Street-Level to System-Level Bureaucracies: How Information and Communication Technology is Transforming Administrative Discretion and Constitutional Control, „Public Administration Review” 2002, vol. 62, no. 2.

Brol M., Racjonalizacja działalności organizacji zbiurokratyzowanych, "Optimum. Studia Ekonomiczne" 2013, nr 1(61).

Crozier M., Biurokracja. Anatomia zjawiska, tłum. S. Łypacewicz, Warszawa 1967.

Drenda L., Biurokracja a wolność społeczeństwa w systemie rynkowym, „Studia Ekonomiczne" 2013, t. 130.

Jaroszyński M., Zagadnienia samorzadu, „Państwo i Prawo” 1974, z. 6.

Jemielniak D., Wobronie biurokracji, „Master of Business Administration” 2010, nr 2.

Kodeks postępowania administracyjnego. Komentarz, pod red. R. Hausera, M. Wierzbowskiego, Warszawa 2018.

Kulesza M., Sześciło D., Polityka administracyjna i zarządzanie publiczne, Warszawa 2013.

Leszczyński L., Europejski Kodeks Dobrej Administracji a zasady polskiej procedury administracyjnej, w: Europeizacja prawa administracyjnego, pod red. I. Rzucidło, Lublin 2011.

Lipsky M., Street-Level Bureaucracy: The Dilemmas of the Individual in Public Services, New York 1980.

Merton R.K., Teoria socjologiczna i struktura społeczna, tłum. E. Morawska, J. Wertenstein-Żuławski, Warszawa 2002.

Reagan R., Moja wizja Ameryki. Najważniejsze przemówienia 40. prezydenta Stanów Zjednoczonych, Warszawa 2004.

Skóra A., Wspótuczestnictwo w postępowaniu administracyjnym, Warszawa 2009.

Supernat J., Biurokratyczne załatwianie spraw jako przedmiot skargi powszechnej - uwagi de lege lata $i$ de lege ferenda, w: Kodyfikacja postępowania administracyjnego na 50-lecie K.P.A., pod red. J. Niczyporuka, Lublin 2010.

Sztandar-Sztanderska K., Czego nie widać? Literatura o polityce rynku pracy a praktyki urzędników pierwszego kontaktu, „Studia z Polityki Publicznej” 2017, nr 2(14).

Sztandar-Sztanderska K., Obywatel spotyka państwo. O urzędach pracy jako biurokracji pierwszego kontaktu, Warszawa 2016.

Świątkiewicz J., Europejski Kodeks Dobrej Administracji (tekst i komentarz o zastosowaniu kodeksu w warunkach polskich procedur administracyjnych), Warszawa 2002.

Trochymiak M., Uznaniowość w pomocy społecznej. Działania pracowników socjalnych w świetle koncepcji street-level bureaucracy, "Polityka Społeczna” 2018, nr 9.

Weber M., Gospodarka i społeczeństwo. Zarys socjologii rozumiejacej, tłum. D. Lachowska, Warszawa 2002.

Żyrek-Horodyska E., Biurokracja PRL-u w dokumencie Krzysztofa Kieślowskiego w kontekście powieści "Urząd” Tadeusza Brezy i publikacji z „Trybuny Ludu”, „Konteksty Kultury" 2015, t. 12, z. 3. 